\title{
Neural cell responses to wear debris from metal-on-metal total disc replacements
}

\author{
H. Lee ${ }^{1} \cdot$ J. B. Phillips ${ }^{2} \cdot$ R. M. Hall ${ }^{1} \cdot$ Joanne L. Tipper ${ }^{1,3}$ (1)
}

Received: 30 April 2019 / Revised: 16 September 2019 / Accepted: 5 October 2019 / Published online: 29 October 2019

(c) The Author(s) 2019

\section{Purpose}

Abstract Total disc replacements, comprising all-metal articulations, are compromised by wear and particle production. Metallic wear debris and ions trigger a range of biological responses including inflammation, genotoxicity, cytotoxicity, hypersensitivity and pseudotumour formation, therefore we hypothesise that, due to proximity to the spinal cord, glial cells may be adversely affected.

Methods Clinically relevant cobalt chrome $(\mathrm{CoCr})$ and stainless steel $(\mathrm{SS})$ wear particles were generated using a six-station pin-on-plate wear simulator. The effects of metallic particles $\left(0.5-50 \mu \mathrm{m}^{3}\right.$ debris per cell) and metal ions on glial cell viability, cellular activity (glial fibrillary acidic protein (GFAP) expression) and DNA integrity were investigated in 2D and 3D culture using live/dead, immunocytochemistry and a comet assay, respectively.

Results CoCr wear particles and ions caused significant reductions in glial cell viability in both 2D and 3D culture systems. Stainless steel particles did not affect glial cell viability or astrocyte activation. In contrast, ions released from SS caused significant reductions in glial cell viability, an effect that was especially noticeable when astrocytes were cultured in isolation without microglia. DNA damage was observed in both cell types and with both biomaterials tested. CoCr wear particles had a dose-dependent effect on astrocyte activation, measured through expression of GFAP.

Conclusions The results from this study suggest that microglia influence the effects that metal particles have on astrocytes, that SS ions and particles play a role in the adverse effects observed and that SS is a less toxic biomaterial than CoCr alloy for use in spinal devices.

\section{Graphic abstract}

These slides can be retrieved under Electronic Supplementary Material.
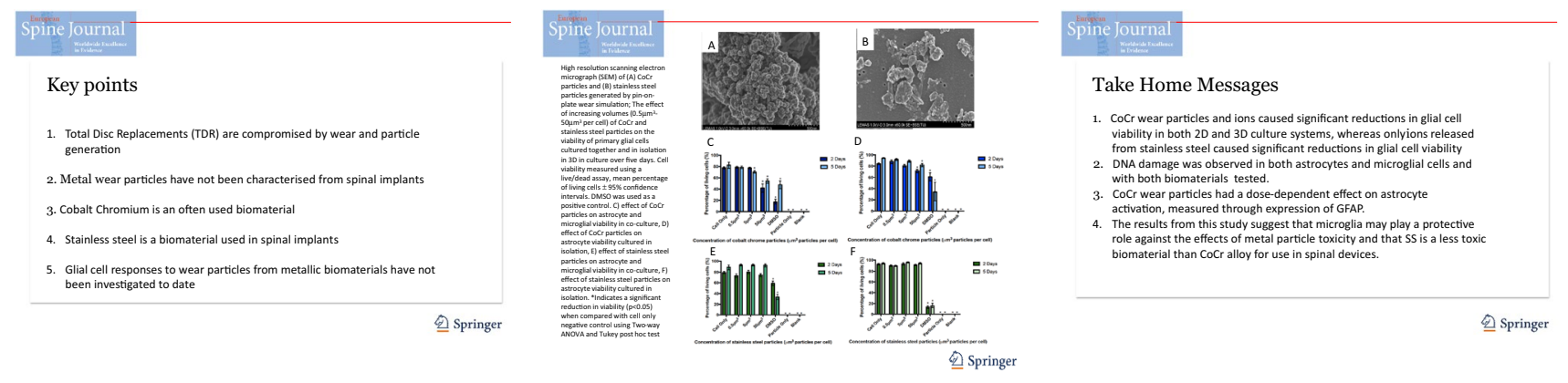

Keywords Total disc replacements (TDR) $\cdot$ Metal wear particles $\cdot$ Cobalt chromium $\cdot$ Stainless steel $\cdot$ Glial cells

Electronic supplementary material The online version of this article (https://doi.org/10.1007/s00586-019-06177-w) contains supplementary material, which is available to authorized users.

Joanne L. Tipper

Joanne.Tipper@uts.edu.au

Extended author information available on the last page of the article

\section{Introduction}

Significant economic and patient issues associated with early failure of metal-on-metal (MOM) total hip and resurfacing replacements have been the focus of the public and scientific 
media recently [1]. These events have led to concerns over other MOM implant systems, including those used in spinal surgery, where a number of articulating total disc replacements (TDRs) are still in use. TDRs comprise structures that have a large number of interfaces, e.g. endplate/bone interface, endplate screws and bone as well as the articulating surfaces. All of these interacting surfaces may produce debris and/or ions with the potential to invoke adverse biological responses, which may lead to failure and ultimately device revision. Metallic TDRs generate wear, debris and/ or corrosion products [2-4], therefore cytotoxic and immunological responses may become a significant problem in the future. Of particular concern is a recent case report describing metallosis and the formation of pseudotumours around a metal-on-metal TDR, similar to failing hip resurfacing arthroplasties [5]. There is evidence documenting the release of metallic particulates from other spinal devices and the inflammatory responses that ensue, including cellular infiltrates and cytokine release (predominantly TNF- $\alpha$ ) [6-12]. Clinically there are reports that describe neurological symptoms, including radicular pain and paraparesis, in patients with metallosis associated with spinal devices [7, 13]. Inflammation would appear to be a key factor in the development of such symptoms; however, other reports also describe late operative site pain $[8,9]$.

The effects of ions and metal debris remain largely unknown for the neural structures in the spine. Cells of the central nervous system (CNS) are protected by the meninges. Disruption of these anatomical features makes the spinal cord and adjacent neural structures particularly vulnerable to exposure to tribo-corrosive products. Recent research has shown that porcine dural cells and dural organ cultures exposed to cobalt chromium ( $\mathrm{CoCr}$ ) nanoparticles produced significantly elevated levels of the pro-inflammatory chemokine IL-8 $[14,15]$, which adversely affected the barrier function of the endothelial cell layer [16]. In addition, significant alterations to the structural integrity of the dura mater were observed together with elevated expression of matrix metalloproteinases (MMP-1, 3, 9, 13) and tissue inhibitor of metalloproteinase- 1 indicating that tissue remodelling and collagen fibre loosening were prevalent in the presence of $\mathrm{CoCr}$ particles. In combination, these effects may enhance nanoparticle penetration into the dura mater and enable access to the cord tissue. Indeed, there is evidence that particles introduced epidurally have the ability to cross both the dural barrier in vivo [11] and the blood spinal cord barrier; the latter has been exploited for drug delivery [17]. In addition, it has been shown that rapid CSF fluid flow occurs from the subarachnoid space into the spinal cord canal via the peri-vascular spaces and these may allow nanoparticle access to these tissues $[18,19]$. This has led to the hypothesis that the barrier functions protecting the spinal cord will be compromised by exposure to metal wear particles and/or ions and that subsequent adverse responses to these species by neural cell populations will result in neurotoxicity, leading to complications and subsequent failure of spinal implants. This is likely to be determined by material type, with some materials (e.g. titanium, PEEK) being less neurotoxic and some materials causing adverse effects. It should be noted that both titanium and PEEK are not or are no longer used as bearing materials due to poor tribological properties and inadequate wear resistance of titanium and a lack of evidence regarding the tribological performance of PEEK as a bearing surface compared to the more commonly used polymer, ultra high molecular weight polyethylene (UHMWPE). The present study investigated the response of primary rat glial cells to $\mathrm{CoCr}$ and stainless steel particles and ions from implant biomaterials in 2D and 3D cell culture systems over time. Particulate and ion effects on neural cell viability, DNA integrity and glial fibrillary acidic protein (GFAP) expression in astrocytes were the focus of the study.

\section{Materials and methods}

\section{Wear particle generation and characterisation}

Clinically relevant cobalt-chromium and stainless steel wear particles were generated using an in-house-manufactured pin-on-plate tribometer and distilled water as the lubricant as described by Germain et al. [20]. Both the pin and plate were made from either medical-grade wrought cobalt-chromium alloy (according to ASTM F1537) with a high carbon content or medical-grade stainless steel (316L). Debris was generated using smooth $\left(R_{\mathrm{a}} 0.01-0.02 \mu \mathrm{m}\right)$ counterfaces with a multidirectional motion (rotation $\pm 30^{\circ}$, stroke length $28 \mathrm{~mm}$, frequency $1 \mathrm{~Hz}$ ) and a contact stress of $11 \mathrm{MPa}$ over $80 \mathrm{~h}$. For particle characterisation, $1 \mathrm{ml}$ aliquot of each lubricant was sequentially filtered through 5-, 1-, 0.1- and $0.015-\mu \mathrm{m}$-sized polycarbonate filters (Whatman) and filters examined using high-resolution scanning electron microscopy (SEM), at magnifications up to $\times 150 \mathrm{~K}$, combined with energy-dispersive X-ray (EDX) analysis to determine particle composition. Particle size and area distributions were generated using Image Pro Plus 6.0 (Media Cybernetics, USA). Stock solutions $\left(1 \mathrm{mg} \mathrm{ml}^{-1}\right)$ of each debris type were generated from sterile, endotoxin-free particles [20]. Particles were dispersed by sonication prior to use.

\section{Neural cell isolation and culture}

All experiments were performed according to the UK Animals (Scientific Procedures) Act (1986) and approved by the appropriate institutional ethical committee. Primary astrocyte cultures were prepared from the cortices of postnatal 2-day-old Wistar rat pups as described by East et al. [21]. 
The tissue was chopped and cells isolated by incubation with $250 \mu \mathrm{g} \mathrm{ml}^{-1}$ trypsin. Digests were repeatedly triturated using a 1-ml pipette to break down any larger clumps of tissue. The resultant cells were resuspended in Dulbecco's modified Eagle's medium (DMEM) supplemented with penicillin/ streptomycin (100 $\mathrm{U} \mathrm{ml}^{-1}$ and $100 \mu \mathrm{g} \mathrm{ml}^{-1}$, respectively) and with $10 \%(\mathrm{v} / \mathrm{v})$ foetal calf serum (FCS). This suspension was dispensed into tissue culture flasks that had been coated with poly-D-lysine $\left(50 \mu \mathrm{g} \mathrm{ml}^{-1}\right)$ and placed in a humidified incubator at $37{ }^{\circ} \mathrm{C}$ with $5 \% \mathrm{CO}_{2} / 95 \%$ air. Cells were expanded in culture for 10-14 days to reach confluence. After this time, cell types were separated by shaking at $150 \mathrm{rpm}$ for $4 \mathrm{~h}$ to remove microglia and less adherent cell types from the resulting astrocytes. Both cell types were passaged into fresh media before being exposed to wear particles and/or ions.

\section{Culture of cells with particles and ions}

Primary rat astrocytes and microglia in isolation and in co-culture were cultured with $\mathrm{CoCr}$ or stainless steel wear particles or ions $\left(0.05-50 \mu \mathrm{m}^{3}\right.$ per cell) for up to 5 days in both $2 \mathrm{D}$ and $3 \mathrm{D}$ culture systems. In the $2 \mathrm{D}$ system, cells were seeded at $1 \times 10^{4}$ cells per well $(n=6)$ in supplemented DMEM medium in poly-D lysine-coated 96 -well plates. Particles were added, and cell viability was assessed after 1, 3 and 5 days using the ATP-Lite assay (PerkinElmer, Windsor, UK). DNA damage was also assessed using the alkaline Comet assay (Trevigen, Maryland, USA) at 24-h, 48-h and 5-day time points [22]. After staining with SYBR Gold (Thermo Fisher Scientific, UK), slides were imaged using a Zeiss fluorescent microscope and the Olive tail moment was used to calculate DNA damage over time using Comet IV Lite software (Perceptive Instruments, UK). Data were expressed as mean comet tail moment $\pm 95 \%$ confidence limits $(n=6)$.

For 3D systems, cells were seeded at $1 \times 10^{6} \mathrm{ml}^{-1}$ into collagen gels (First Link, UK; $2 \mathrm{mg} \mathrm{m}^{-1}$ ) along with the appropriate volume of particles suspended in DMEM. A volume of $100 \mu \mathrm{l}$ of collagen gel containing cells and particles was seeded into 96-well plates. Particles were dosed at 0.5, $5,50 \mu \mathrm{m}^{3}$ per cell $(n=6)$, and cell viability assessed using a live/dead cytotoxicity assay for mammalian cells (Thermo Fisher Scientific, UK) after $48 \mathrm{~h}$ and 5 days in culture. The expression of glial fibrillary acidic protein (GFAP), a marker of astrocyte activation and reactive gliosis, was assessed at the same time points using a polyclonal primary antibody (Agilent Technologies UK Ltd) and an anti-rabbit DyLight ${ }^{\circledR}$ 549 (Vector Laboratories, UK) secondary antibody. Hoescht 33258 was used to stain cell nuclei. Cells were imaged at six locations within each gel $(n=6)$ using a LSM510 confocal laser scanning microscope (Carl Zeiss Ltd) leading to 36 images per test. The number of live and dead cells were calculated, and immunopositive cells were scored (images were negative (GFAP expression not detectable) or positive (GFAP upregulated to detectable level)) using ImageJ software (NIH, USA) compared to the negative control images.

For the culture of primary glial cells with $\mathrm{CoCr}$ or SS ions, the appropriate mass of particles (equivalent to 0.5 , $5,50 \mu \mathrm{m}^{3}$ particles per cell) was incubated with supplemented DMEM for $24 \mathrm{~h}$ at $37{ }^{\circ} \mathrm{C}$ in $5 \%$ (v/v) $\mathrm{CO}_{2}$ in air with agitation. The particle suspensions were centrifuged at $160,000 \times g$, and the supernatants containing ions were added to wells containing cells suspended in collagen gel. The same assays as described above were performed to assess the effect of metal ions on cell viability and the expression of GFAP.

\section{Statistical analysis}

Data were presented as mean $\pm 95 \%$ confidence limits of the mean and statistical analysis performed using a twoway ANOVA. Significant differences between means were determined using Tukey's post hoc analysis. A $p$ value of $p<0.05$ was indicative of statistical significance.

\section{Results}

\section{Characterisation of cobalt chromium and stainless steel particles}

Particles were isolated through sequential filtration through $5-, 1-, 0.1-$ and $0.015-\mu \mathrm{m}$ filters, which were coated with platinum and imaged using high-resolution FEGSEM. Cobalt chromium particles were viewed as agglomerates on all filters (Fig. 1a-d). At higher magnifications $(>\times 30 \mathrm{~K})$ on the 0.1 - and $0.015-\mu \mathrm{m}$ filters, particles were round to oval and in the nanoscale. The majority of particles produced were between 10 and $120 \mathrm{~nm}$, and the mode was $30-39 \mathrm{~nm}$ (Fig. 2). Particles were identified as comprising cobalt, chromium, molybdenum and oxygen as the major elements (Online Resources 1). Stainless steel particles were observed as irregular granular particles on the larger pore size filters and round nanoscale particles on the smaller pore size filters (Fig. 3a-d). The particles ranged in size from $10 \mathrm{~nm}$ to larger than $1 \mathrm{~mm}$, and the mode was between 30 and $39 \mathrm{~nm}$ (Fig. 4) similar to CoCr. The elemental composition of the stainless steel particles was comprised largely of iron and nickel plus carbon and oxygen (Online Resource 2).

\section{The effect of $\mathrm{CoCr}$ and stainless steel particles on primary astrocytes and microglia in 2D culture}

The effect of increasing volumes of cobalt chrome particles on the viability of primary astrocytes and microglia in $2 \mathrm{D}$ 

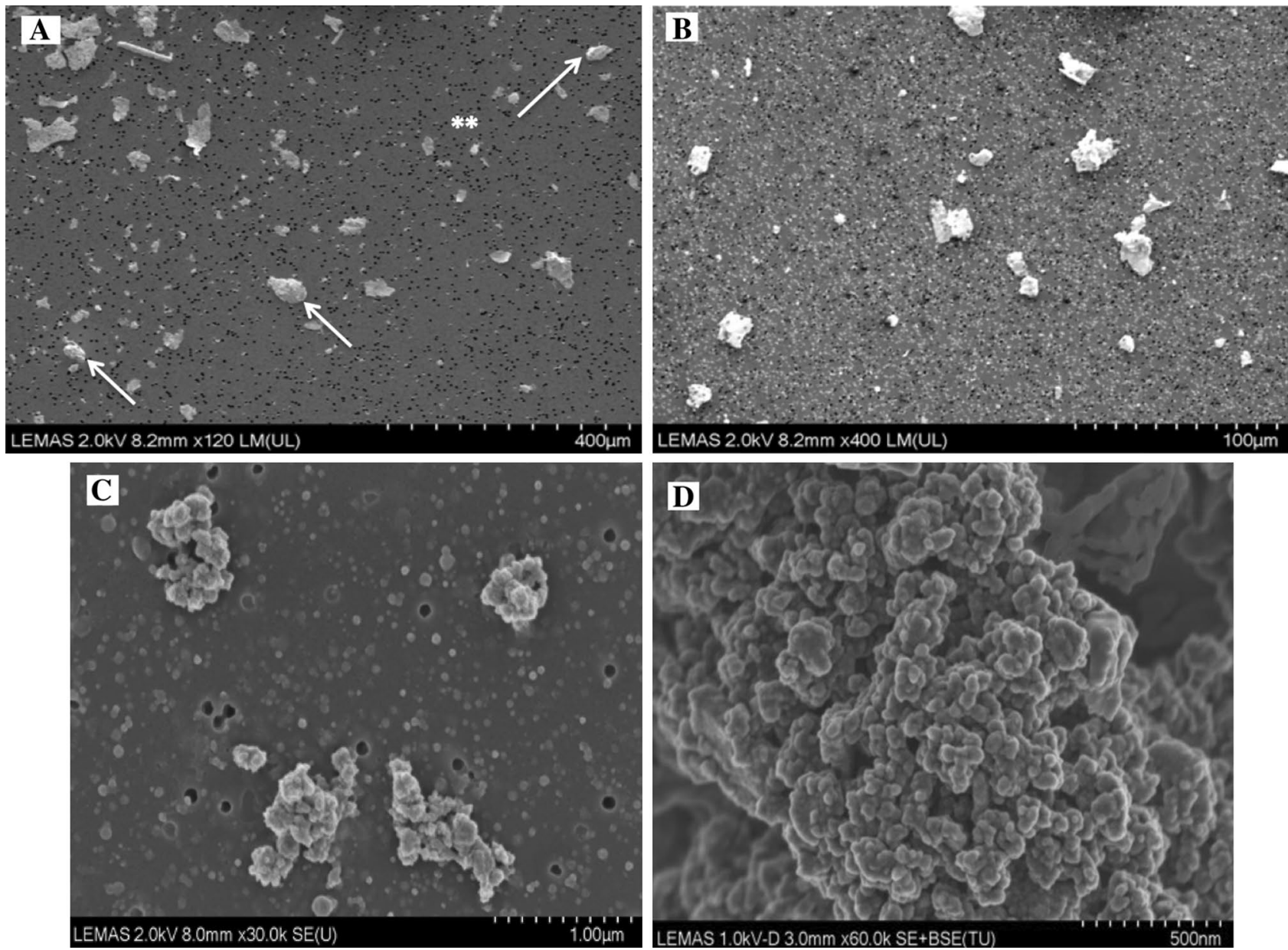

Fig. 1 High-resolution FEGSEM images of cobalt chromium particles generated by pin-on-plate simulation in water lubricant. a Aggregate particles isolated on a $5-\mu \mathrm{m}$ filter, $\times 120$ magnification; $\mathbf{b}$ aggregates of cobalt chromium particles isolated on a $1-\mu \mathrm{m}$ filter, $\times 400$ magnification; $\mathbf{c}$ aggregates of cobalt chromium particles isolated on

a $0.1-\mu \mathrm{m}$ filter, $\times 30,000$ magnification; $\mathbf{d}$ high-magnification image of cobalt chromium aggregates isolated on a $0.1-\mu \mathrm{m}$ filter, $\times 60,000$ magnification. Arrows indicate large irregular micron-sized particles.

** indicates agglomerate of submicron-sized particles
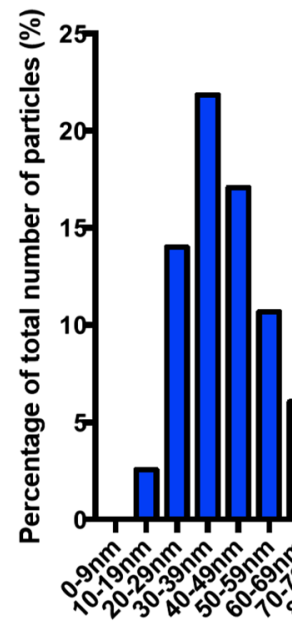

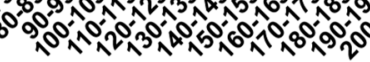

Particle size (length) $\mathrm{nm}$

Fig. 2 Size distribution of cobalt chromium particles generated in a six-station pin-on-plate wear simulator using water as the lubricant 

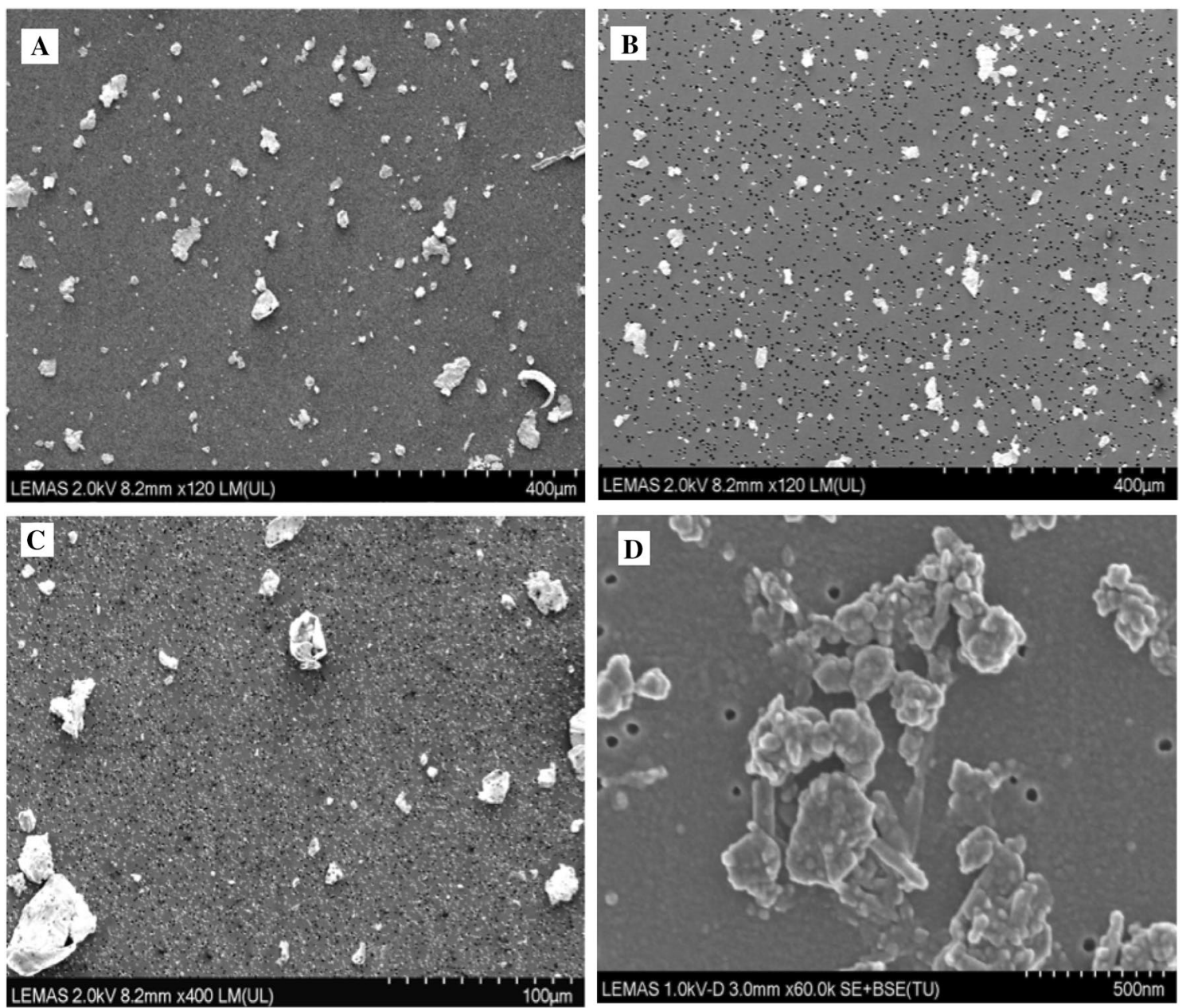

Fig. 3 High-resolution FEGSEM images of stainless steel particles generated by pin-on-plate simulation in water lubricant. a Aggregate particles isolated on a 5- $\mu \mathrm{m}$ filter, $\times 120$ magnification; $\mathbf{b}$ aggregates of stainless steel particles isolated on a $1-\mu \mathrm{m}$ filter, $\times 120$ magnifica-

co-culture was assessed using the ATP-Lite ${ }^{\mathrm{TM}}$ assay over time. After $24 \mathrm{~h}$, there were no significant effects on cell viability; however, after 3 and 5 days in culture a statistically significant reduction in viability was observed for all particle doses (Fig. 5a; $p<0.05$, ANOVA). With stainless steel particles, there was an initial adverse effect on viability observed after $24 \mathrm{~h}$ at concentrations of between 0.5 and $50 \mu \mathrm{m}^{3}$ per cell and at day 5 at the highest particle dose only (Fig. 5b; $p<0.05$, ANOVA).

Only the highest concentration of $\mathrm{CoCr}$ particles $\left(50 \mu \mathrm{m}^{3}\right.$ per cell) had a significant effect on DNA integrity in the first $24 \mathrm{~h}$ of culture (Fig. $6 \mathrm{a} ; p<0.05$ ANOVA plus Tukey). After $48 \mathrm{~h}$, all concentrations of $\mathrm{CoCr}$ particles adversely affected DNA integrity; however, after 5 days only the $50 \mu^{3}$ particle concentration caused a significant increase in DNA damage (Fig. 6a). When astrocytes were cultured in isolation in 2D monolayer culture with $\mathrm{CoCr}$ particles, all particle concentrations caused significant DNA damage

tion; c aggregates of stainless steel particles isolated on a $1-\mu \mathrm{m}$ filter, $\times 400$ magnification; $\mathbf{d}$ high-magnification image of stainless steel aggregates isolated on a $0.1-\mu \mathrm{m}$ filter, $\times 60,000$ magnification

from $24 \mathrm{~h}$ onwards (Fig. 6b; $p<0.05$ ANOVA and Tukey). Stainless steel particles compromised DNA integrity from $24 \mathrm{~h}$, an effect that was dose dependent (Fig. 6c). When primary astrocytes were cultured in isolation with stainless steel particles, significant effects on DNA integrity were observed at 2 and 5 days with the 5 and $50 \mu \mathrm{m}^{3}$ particle per cell concentrations (Fig. 6d; $p<0.05$ ANOVA and Tukey).

\section{The effect of $\mathrm{CoCr}$ and stainless steel particles on primary astrocytes and microglia in 3D culture}

A live/dead assay was used to determine the effect of wear particles on the viability of primary astrocytes and microglia in co-culture and primary astrocytes in isolation in a 3D collagen hydrogel cell culture system. Gels were imaged using fluorescence microscopy, and the percentage of living cells calculated. After 2 days in culture, $50 \mu^{3}$ of CoCr particles adversely affected cell viability (Fig. $7 \mathrm{a} ; p<0.05$ ANOVA 


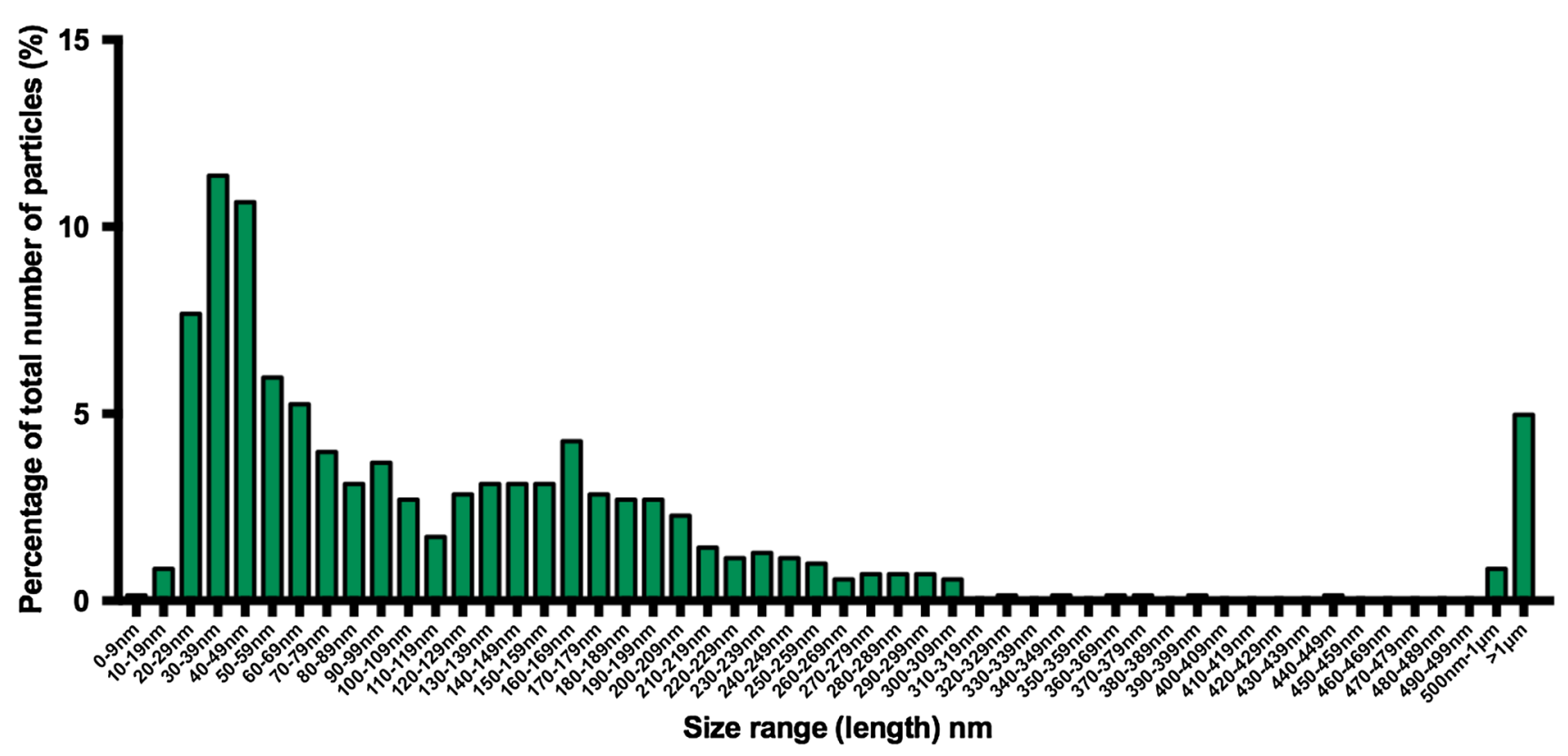

Fig. 4 Size distribution of stainless steel particles generated in a six-station pin-on-plate wear simulator using water as the lubricant

plus Tukey). After 5 days in culture, both the 5 and $50 \mu \mathrm{m}^{3}$ per cell of CoCr particles significantly reduced cell viability (Fig. 7a; $p<0.05$, ANOVA and Tukey's post hoc test). Significant effects on viability were observed when the primary astrocytes were cultured with only the $50 \mu^{3} \mathrm{CoCr}$ particle concentration after 2 and 5 days in culture (Fig. $7 \mathrm{~b} ; p<0.05$ ANOVA and Tukey's post hoc test).

No adverse effects on cell viability were observed when primary astrocytes and microglia were cultured together or in isolation with any concentration of stainless steel debris at any time point (Fig. 7c, d).

\section{The effect of ions released from $\mathrm{CoC} r$ and stainless steel wear debris on the viability of primary astrocytes and microglia in 3D culture}

There were no adverse effects on cell viability of $\mathrm{CoCr}$ ions at any concentration at the 48-h time point (Fig. 8a). However, a significant reduction in viability at the $5 \mu \mathrm{m}^{3}$ per cell concentration of cobalt chrome ions was observed after 5 days in culture (Fig. 8a; $p<0.05$ ANOVA and Tukey's post hoc test). When primary astrocytes were cultured in isolation with $\mathrm{CoCr}$ ions, all doses affected cell viability significantly (Fig. 8b; $p<0.05$, ANOVA and Tukey's post hoc test) after 2 days. After 5 days, the ions released from $5 \mu \mathrm{m}^{3}$ and $50 \mu^{3} \mathrm{CoCr}$ particles significantly affected cell viability (Fig. 8b). No adverse effects were observed when primary astrocytes and microglia were cultured in 3D co-culture with ions released from stainless steel particles at concentrations of 0.5 and $5 \mu \mathrm{m}^{3}$ per cell (Fig. 8c). However, after 5 days in culture, ions from the highest concentration of stainless steel debris (50 $\mu^{3}$ per cell) adversely affected cell viability (Fig. 8c; $p<0.05$ ANOVA and post hoc Tukey's test). When astrocytes were cultured in isolation with ions from stainless steel particles, after 2 days only the $5 \mu^{3}$ per cell concentration had a significant effect on cell viability; however, by day 5 all concentrations of ions adversely affected cell viability (Fig. 8d).

\section{The effect of $\mathrm{CoCr}$ and stainless steel wear particles on the level of expression of glial fibrillary acidic protein (GFAP) in primary astrocytes in the presence and absence of microglia}

When primary astrocytes were co-cultured with microglia in $3 \mathrm{D}$ culture with $\mathrm{CoCr}$ particles $\left(0.5-50 \mu \mathrm{m}^{3}\right.$ per cell), the highest concentration of particles $\left(50 \mu \mathrm{m}^{3}\right.$ per cell) resulted in increased expression of GFAP at both the 2- and 5-day time point (Table 1). However, lower concentrations of $\mathrm{CoCr}$ wear particles only caused increased expression of GFAP after 5 days. Stainless steel particles failed to increase GFAP expression to detectable levels in astrocytes at any particle concentration at any time point. When primary astrocytes were cultured in isolation in $3 \mathrm{D}$ 


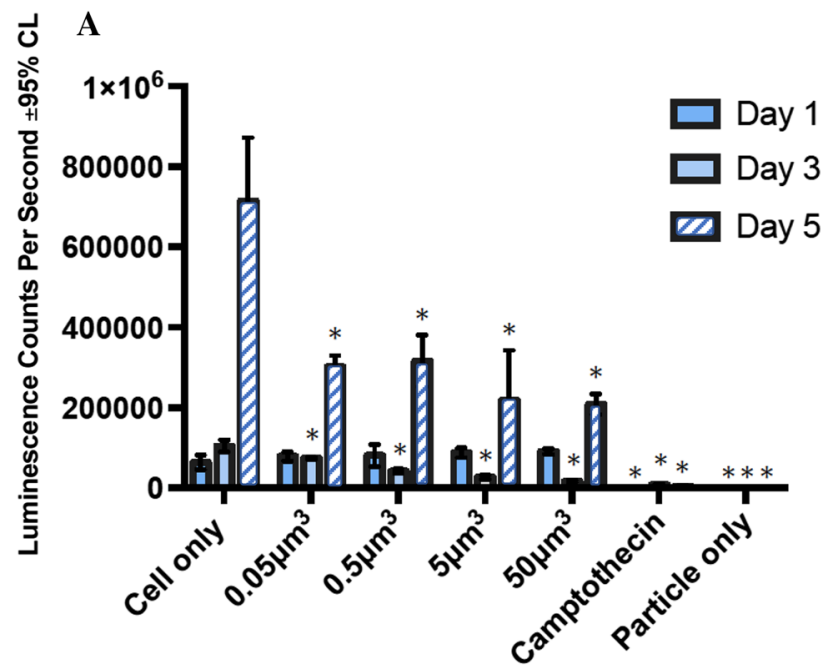

Cobalt chrome particle volume $\left(\mu \mathrm{m}^{3}\right.$ particles per cell)

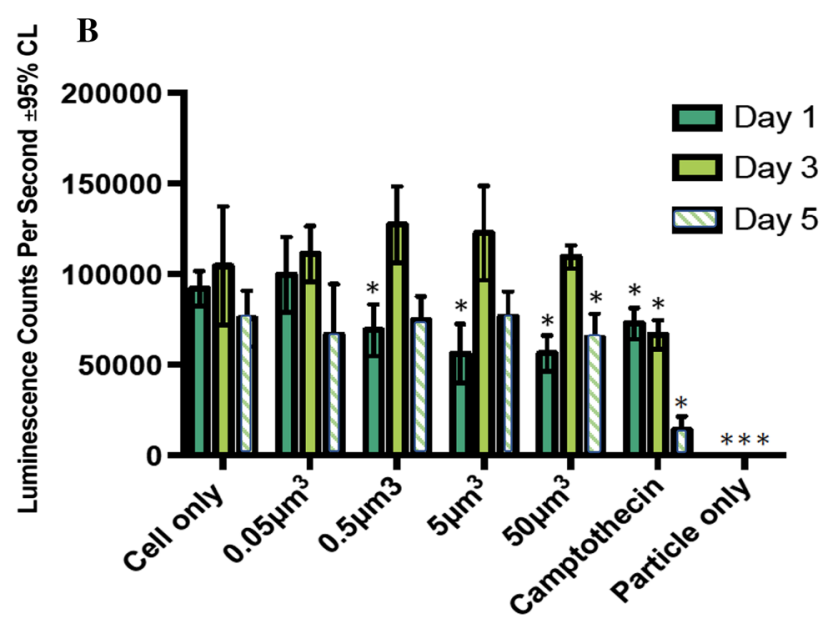

Stainless steel particle volume ( $\mu \mathrm{m}^{3}$ particles per cell)

Fig. 5 The effect of cobalt chrome and stainless steel particles on the viability of primary astrocytes and microglia in co-culture in $2 \mathrm{D}$ monolayer culture over 5 days. Cell viability measured using ATPLite assay after exposure to increasing concentrations of $\mathbf{a} \mathrm{CoCr}$ and b stainless steel particles; *significant difference between means (two-way ANOVA plus Tukey, $p<0.05$ ) when compared to the cell only negative control

culture with $\mathrm{CoCr}$ wear particles, the 5 and $0.5 \mu \mathrm{m}^{3}$ per cell concentrations of particles increased the expression of GFAP after 5 days. Again, stainless steel particles did not cause increased expression of GFAP at any concentration or time point (Table 2).

\section{Discussion}

\section{Characterisation of wear particles}

The particles of $\mathrm{CoCr}$ generated in this study were similar in terms of size and morphology to previous studies [20,
22], and comparable to those generated in metal-on-metal total disc replacement devices [2]. The stainless steel particles were similar in morphology to the CoCr particles; however, their size range was larger, which is in line with the different material properties of the two metals, particularly with respect to chemistry, hardness and microstructure, e.g. grain size [23].

\section{Effects of wear particles on cell viability and DNA integrity in 2D culture}

When $\mathrm{CoCr}$ wear particles were cultured with primary rat astrocytes and microglial cells in 2D culture, cell viability was adversely affected by all doses of particles. This is in line with previous studies that exposed monocytes and fibroblasts to CoCr wear particles [20]. When cells were exposed to stainless steel particles in 2D culture, initially an adverse effect was observed; however, this effect was only consistent at the highest particle concentration at the 5-day time point. Other studies have observed variable cellular toxicity associated with stainless steel particles, with some cell types, e.g. monocytes adversely affected [24] and others not affected, e.g. osteoblasts [25]. The different effects are postulated to be due to different sensitivities of cell lines and different compositions of the two metals, with $\mathrm{CoCr}$ having higher chromium content than stainless steel (27-30\% compared to $16-18 \%$ ) and the absence of cobalt in stainless steel [26].

When glial cells were exposed to $\mathrm{CoCr}$ and SS particles and DNA integrity analysed, again there were differences between the two biomaterials. High doses of $\mathrm{CoCr}$ particles significantly affected DNA integrity of glial cells. In isolation, astrocytes were more sensitive to CoCr particles. These results suggested that when microglial cells were present, these cells influenced the effects that the particles had on the astrocyte cells, often with the microglial cells experiencing adverse effects in the form of DNA damage, whilst appearing to protect the astrocytes from these effects in the co-culture. After culture with SS particles, adverse effects on glial cell DNA integrity were observed after $24 \mathrm{~h}$ with all concentrations of particles. In contrast, astrocytes in isolation were not affected by stainless steel particles.

\section{Effects of wear particles and ions on cell viability and cell reactivity in 3D culture}

When primary astrocytes and microglia were cultured with increasing particle volumes of $\mathrm{CoCr}$, a dose-dependent effect on cell viability was observed. When primary astrocytes were cultured in isolation with increasing particle volumes of $\mathrm{CoCr}$, only the highest particle dose significantly reduced cell viability. Interestingly, the removal of microglia from the culture environment appeared to reduce the sensitivity 


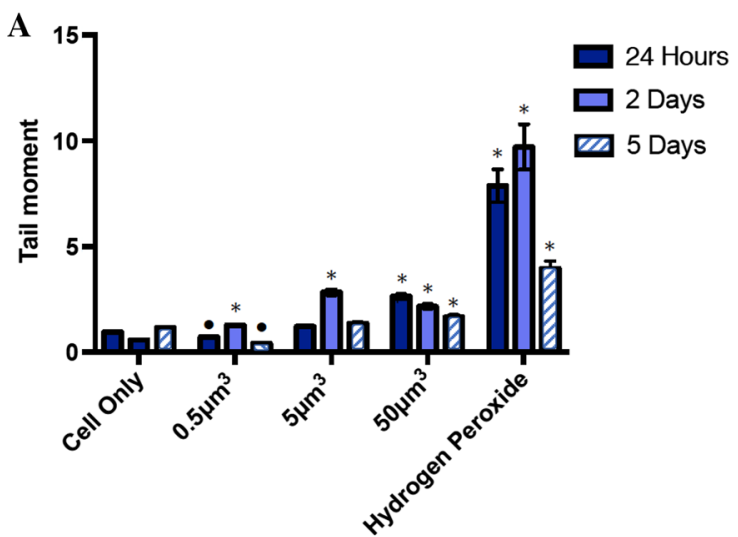

Cobalt chrome particle concentration ( $\mu \mathrm{m}^{3}$ debris per cell)

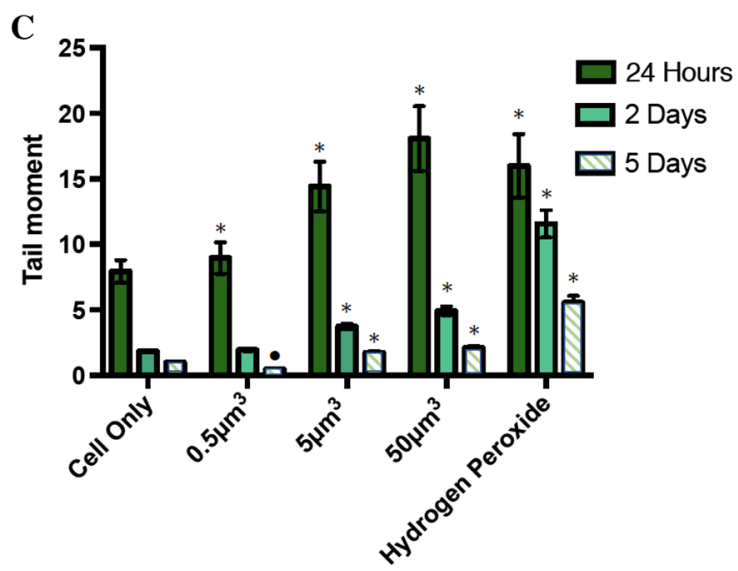

Stainless steel particle concentration ( $\mu \mathrm{m}^{3}$ debris per cell)

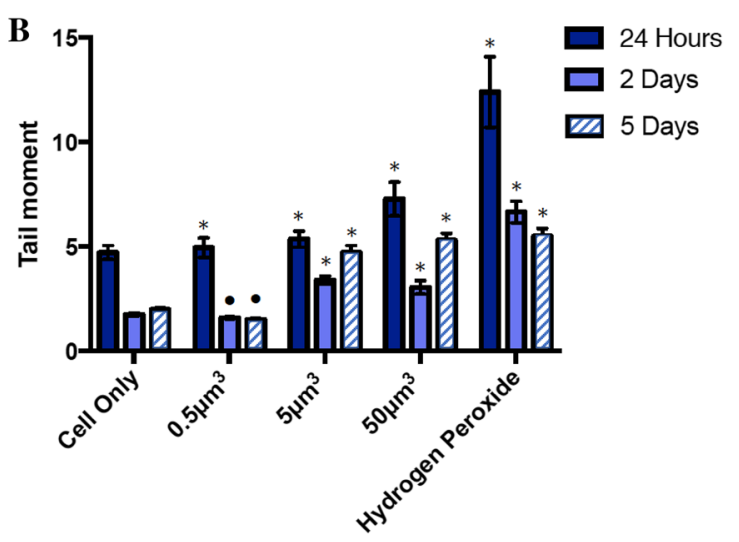

Cobalt chrome particle concentration ( $\mu \mathrm{m}^{3}$ debris per cell)

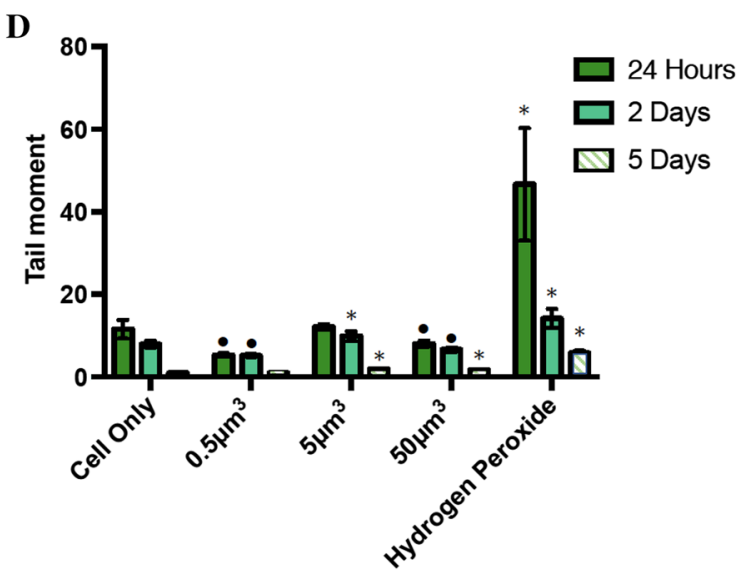

Stainless steel particle concentration ( $\mu \mathrm{m}^{3}$ debris per cell)

in co-culture, $\mathbf{d}$ effect of stainless steel particles on astrocyte DNA cultured in isolation. *Indicates a significant increase in the level of DNA damage expressed as a value for tail moment $(p<0.05)$ when compared with cell only negative control using two-way ANOVA. - Indicates a significant decrease in the level of DNA damage expressed as a value for tail moment $(p<0.05)$ when compared with cell only negative control using two-way ANOVA

time point. These results echo the results in the $2 \mathrm{D}$ culture system, indicating that differences in elemental composition between the two biomaterials may be responsible for the different effects on cell viability. In contrast, adverse effects on cell viability were observed when glial cells were exposed to ions from stainless steel particles, particularly when astrocytes were cultured in isolation, indicating that in the absence of microglia, astrocytes were more sensitive to ions from implant biomaterials.

Upregulation of the expression of glial fibrillary acidic protein (GFAP) to a variety of stimulants including injury [21] and biomaterial particles [27] has been widely reported in the literature. $\mathrm{CoCr}$ particles caused increased expression of GFAP at low particle concentrations by the 5-day time 


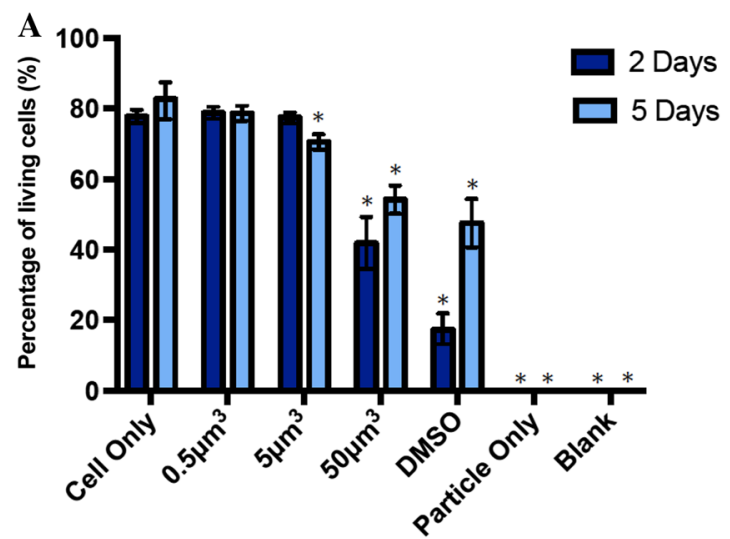

Concentration of cobalt chrome particles $\left(\mu \mathrm{m}^{3}\right.$ particles per cell)

C

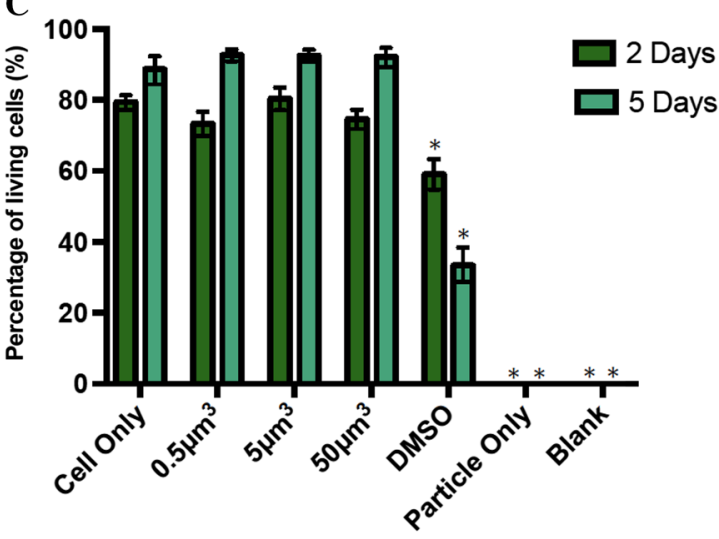

Concentration of stainless steel particles $\left(\mu \mathrm{m}^{3}\right.$ particles per cell)

Fig. 7 The effect of increasing volumes $\left(0.5-50 \mu \mathrm{m}^{3}\right.$ per cell) of $\mathrm{CoCr}$ and stainless steel particles on the viability of primary glial cells cultured together and in isolation in 3D in culture over 5 days. Cell viability measured using a live/dead assay, mean percentage of living cells $\pm 95 \%$ confidence intervals. DMSO was used as a positive control. a Effect of $\mathrm{CoCr}$ particles on astrocyte and microglial viabil-

point; however, often the higher concentrations of particles did not. We postulate that these higher particle concentrations caused significant reductions in cell viability, and with a large proportion of the cells dead or dying, this masked the detection of GFAP. Stainless steel particles had no effect on the GFAP expression in glial cells at any dose or any time point.

In summary, $\mathrm{CoCr}$ particles adversely affected glial cell viability and triggered increased GFAP expression, indicating that astrocytes developed a reactive phenotype and were subjected to significant DNA damage. Cobalt chromium ions also had adverse effects on cell viability. In contrast, stainless steel particles rarely affected cell viability and did not elicit increased expression of GFAP. However, SS particles

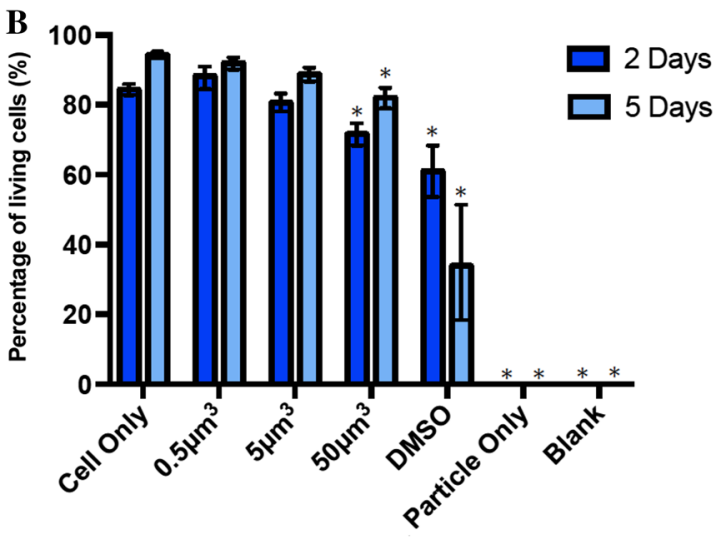

Concentration of cobalt chrome particles ( $\mu \mathrm{m}^{3}$ particles per cell)

D

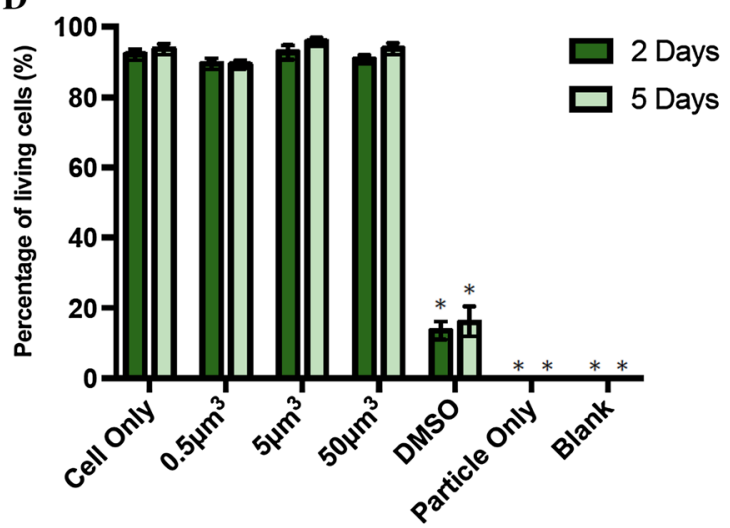

Concentration of stainless steel particles $\left(u \mathrm{~m}^{3}\right.$ particles per cell)

ity in co-culture, $\mathbf{b}$ effect of CoCr particles on astrocyte viability cultured in isolation, $\mathbf{c}$ effect of stainless steel particles on astrocyte and microglial viability in co-culture, $\mathbf{d}$ effect of stainless steel particles on astrocyte viability cultured in isolation. *Indicates a significant reduction in viability $(p<0.05)$ when compared with cell only negative control using two-way ANOVA and Tukey's post hoc test

caused significant DNA damage and glial cells appeared to be more sensitive to stainless steel ions compared to $\mathrm{CoCr}$ ions, where the former were found to adversely affect cell viability at low concentrations and early time points. The results indicated that DNA damage was the result of interaction with ionic species rather than the particles themselves.

The particles used in the present study were generated using a simple configuration pin-on-plate wear simulator using water as a lubricant. In a previous study [2], the biocompatibility of $\mathrm{CoCr}$ wear particles generated from $\mathrm{CoCr}$ alloy on $\mathrm{CCr}$ alloy TDRs in serum and water was compared with particles generated in water using the same pin-on-plate set-up used in the present study. In L929 fibroblast cells, Pasko [2] found that there was no 


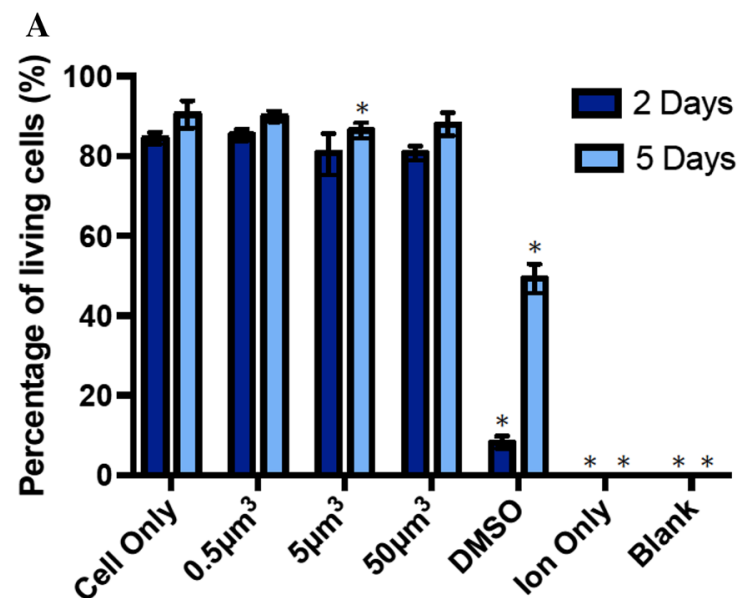

C

Concentration of cobalt chrome ions

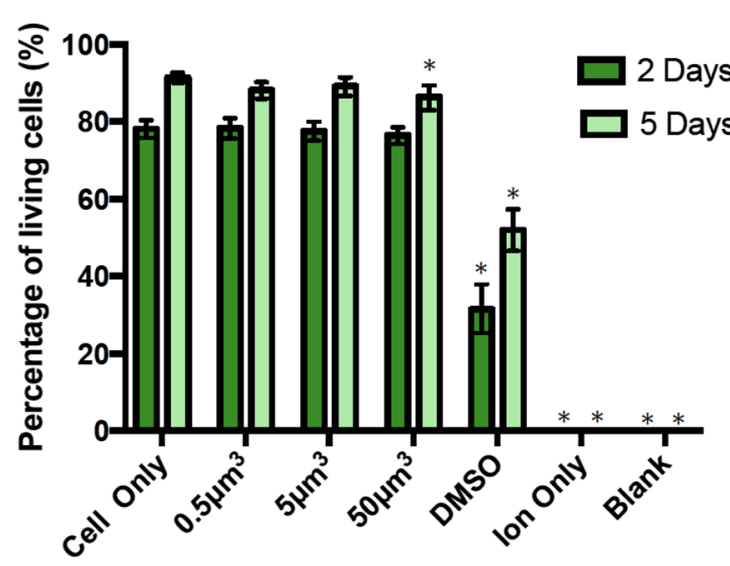

Concentration of stainless steel ions

Fig. 8 The effect of increasing concentrations of ions from $\mathrm{CoCr}$ and stainless steel wear particles $\left(0.5-50 \mu \mathrm{m}^{3}\right)$ on the viability of primary glial cells in 3D co-culture and in isolation over 5 days. Cell viability measured using a live/dead assay, mean percentage of living cells $\pm 95 \%$ confidence intervals. DMSO was used as the positive control. a Effect of $\mathrm{CoCr}$ ions on astrocyte and microglial viability in

difference in the viability of L929 cells exposed to the different types of particles, with higher volumes of particles ( 5 and $50 \mu^{3}$ of particles per cell) causing adverse effects on cell viability in a similar way that $\mathrm{CoCr}$ particles affected neural cells in the present study. The use of particles from joint simulators using serum lubricants causes issues with microbial contamination, endotoxin contamination and degraded proteins, which all affect the cellular responses, making it difficult to determine the effects of the particles alone. Simple configuration pin-on-plate
B

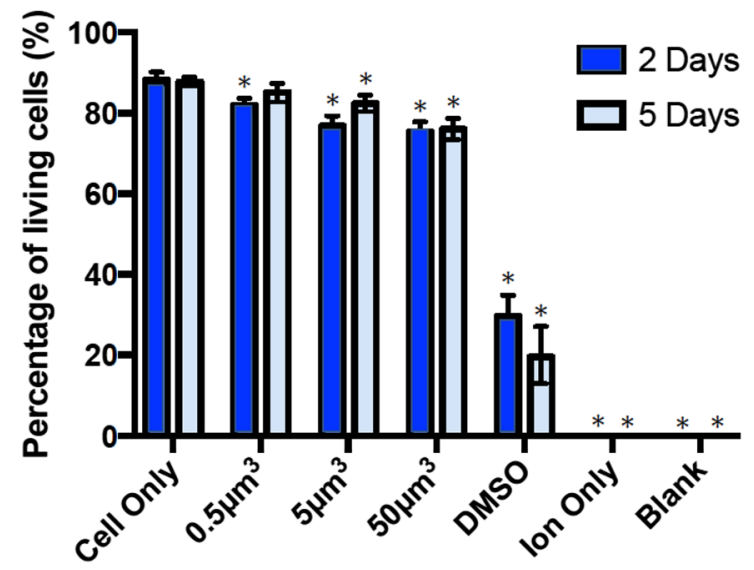

D

Concentration of cobalt chrome ions

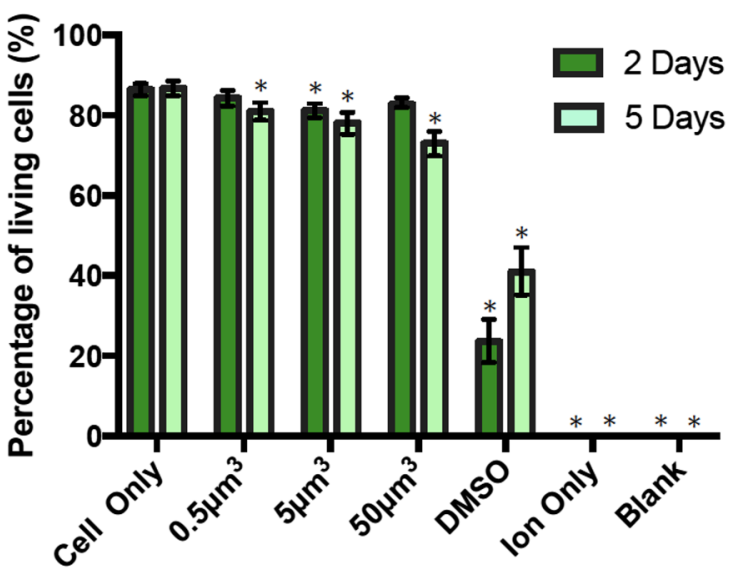

Concentration of stainless steel ions

co-culture, $\mathbf{b}$ effect of $\mathrm{CoCr}$ ions on astrocyte vibility cultured in isolation, $\mathbf{c}$ effect of stainless steel ions on astrocyte and microglial viabilty in co-culture, $\mathbf{d}$ effect of stainless steel ions on astrocyte viability cultured in isolation. *Indicates a significant reduction in viability $(p<0.05)$ when compared with cell only negative control using twoway ANOVA and post hoc Tukey's test

simulators provide a quick, cost-effective way to generate large volumes of debris for cell culture easily avoiding these issues.

This study has revealed for the first time that clinically relevant wear particles from metallic biomaterials have numerous adverse effects on the cells of the spinal cord, and caution should be exercised when using these materials in spinal devices and instrumentation. 
Table 1 The effects of cobalt chrome and stainless steel particles on the expression of GFAP by primary astrocytes in the presence of microglia after 2 and 5 days in culture

\begin{tabular}{lllll}
\hline & $\begin{array}{l}\text { Cobalt } \\
\text { chrome } \\
2 \text { days }\end{array}$ & $\begin{array}{l}\text { Cobalt } \\
\text { chrome } \\
5 \text { days }\end{array}$ & $\begin{array}{l}\text { Stain- } \\
\text { less steel } \\
2 \text { days }\end{array}$ & $\begin{array}{l}\text { Stain- } \\
\text { less steel } \\
5 \text { days }\end{array}$ \\
\hline $\begin{array}{l}50 \mathrm{~m}^{3} \text { debris per } \\
\text { cell }\end{array}$ & + & + & - & - \\
$5 \mu \mathrm{m}^{3}$ debris per & - & + & - & - \\
$\quad \begin{array}{l}\text { cell } \\
0.5 \mu \mathrm{m}^{3} \text { debris per }\end{array}$ & - & + & - & \pm \\
cell & & & & + \\
$\begin{array}{l}\text { TGF- } \beta 1 \text { (positive } \\
\text { control) }\end{array}$ & + & + & + & + \\
$\begin{array}{l}\text { Cell only } \\
\text { Particle only }\end{array}$ & - & - & - & - \\
Blank & - & - & - & - \\
\hline
\end{tabular}

+ indicates the presence of GFAP positive cells, - indicates the absence of GFAP positive cells, \pm indicates equal numbers of GFAP positive and negative cells

Table 2 The effects of cobalt chrome and stainless steel particles on the expression of GFAP by primary astrocytes after 2 and 5 days in culture

\begin{tabular}{lllll}
\hline & $\begin{array}{l}\text { Cobalt } \\
\text { chrome } \\
2 \text { days }\end{array}$ & $\begin{array}{l}\text { Cobalt } \\
\text { chrome } \\
5 \text { days }\end{array}$ & $\begin{array}{l}\text { Stain- } \\
\text { less steel } \\
2 \text { days }\end{array}$ & $\begin{array}{l}\text { Stain- } \\
\text { less steel } \\
5 \text { days }\end{array}$ \\
\hline $\begin{array}{l}50 \mu \mathrm{m}^{3} \text { debris per } \\
\text { cell }\end{array}$ & - & - & - & - \\
$5 \mu \mathrm{m}^{3}$ debris per & - & + & - & - \\
$\quad \begin{array}{l}\text { cell } \\
0.5 \mu \mathrm{m}^{3} \text { debris per }\end{array}$ & - & + & - & - \\
cell & & & & + \\
$\begin{array}{l}\text { TGF-1 } 1 \beta \text { (positive } \\
\text { control) }\end{array}$ & + & + & + & + \\
$\begin{array}{l}\text { Cell only } \\
\text { Particle only }\end{array}$ & - & - & - & - \\
Blank & - & - & - & - \\
\hline
\end{tabular}

+ indicates the presence of GFAP positive cells, - indicates the absence of GFAP positive cells, \pm indicates equal numbers of GFAP positive and negative cells

Acknowledgements The research was funded by the Engineering and Physical Sciences Research Council, UK, through a Ph.D. scholarship to HL through the Centre for Doctoral Training Medical and Biological Engineering, School of Mechanical Engineering, University of Leeds, UK.

\section{Compliance with ethical standards}

Conflict of interest The authors declare that they have no conflict of interest.
Open Access This article is distributed under the terms of the Creative Commons Attribution 4.0 International License (http://creativeco mmons.org/licenses/by/4.0/), which permits unrestricted use, distribution, and reproduction in any medium, provided you give appropriate credit to the original author(s) and the source, provide a link to the Creative Commons license, and indicate if changes were made.

\section{References}

1. BBC News (2012) http://www.bbc.co.uk/news/health-17337993. Accessed 15 Apr 2014

2. Pasko K (2016) Ceramic coatings for cervical total disc replacement. Ph.D. thesis, University of Leeds

3. Pare PE, Chan FW, Powell ML et al (2007) Wear characteristics of the A-MAV anterior motion replacement using a spine wear simulator. Wear 263:1055-1059

4. Kurtz SM, Ciccarelli L, Siskey R et al (2012) Comparison of in vivo and simulator retrieved metal-on-metal cervical disc replacements. Int J Spine Surg 6:145-156

5. Guyer RD, Shellock J, MacLennan B et al (2013) Early failure of metal-on-metal artificial disc prostheses associated with lymphocytic reaction: diagnosis and treatment experience in four cases. Spine 36:E492-E497

6. Mody DR, Esses SI, Heggeness MH (1994) A histologic study of soft tissue reactions to spinal implants. Spine 19:1153-1156

7. Takahashi S, Delecrin J, Passuti N (2001) Intraspinal metallosis causing delayed neurologic symptoms aster spinal instrumentation surgery. Spine 26:1495-1499

8. Gaine WJ, Andrew SM, Chadwick P et al (2001) Late operative site pain with isola posterior instrumentation requiring implant removal. Spine 26:583-587

9. Senaran H, Atilla P, Kaymaz F et al (2004) Ultrastructural analysis of metallic debris and tissue reaction around spinal implants in patients with late operative site pain. Spine 29:1618-1623

10. Cunningham BW, Orbegoso CM, Dmitriev AE et al (2002) The effect of titanium particulate on development and maintenance of a posterolateral spine arthrodesis. Spine 27:1971-1981

11. Cunningham BW, Hallab NJ, Hu N et al (2013) Epidural application of spinal instrumentation particulate wear debris: a comprehensive evaluation of neurotoxicity using an in vivo animal model. J Neurosurg Spine 19:336-350

12. Wang JC, Yu WD, Sandhu HS et al (2002) Metal debris from titanium spinal implants. Spine 24:899-903

13. Yoshihara $\mathrm{H}$ (2013) Rods in spinal surgery: a review of the literature. Spine J 13:1350-1358

14. Papageorgiou I, Marsh L, Tipper JL et al (2014) Interaction of micron and nano-sized particles with cells of the dura mater. $\mathrm{J}$ Biomed Mater Res Part B 102B:1496-1505

15. Behl B, Papageorgiou I, Brown C et al (2014) Biological effects of cobalt chromium particles and ions on dural fibroblasts and dural epithelial cells. Biomaterials 34:3547-3558

16. Papageorgiou I, Abberton T, Fuller M et al (2014) Biological effects of clinically relevant $\mathrm{CoCr}$ nanoparticles in the dura mater: an organ culture study. Nanomaterials 4:485-504

17. Chang B-S, Brown PR, Sieber A et al (2004) Evaluation of the biological response of wear debris. Spine J 4:S239-S244

18. Stoodley MA, Jones NR, Brown CJ (1996) Evidence for rapid fluid flow from the subarachnoid space into the spinal cord central canal in the rat. Brain Res 707:155-164 
19. Stoodley MA, Brown SA, Brown CJ et al (1997) Arterial pulsation-dependent perivascular cerebrospinal fluid flow into the central canal in the sheep spinal cord. J Neurosurg 86:686-693

20. Germain M, Hatton A, Williams S et al (2003) Comparison of the cytotoxicity of clinically relevant cobalt-chromium and alumina ceramic wear particles in vitro. Biomaterials 24:469-479

21. East E, Golding JP, Phillips JB (2009) A versatile 3D culture model facilitates monitoring of astrocytes undergoing reactive gliosis. J Tissue Eng Regen Med 3:634-646

22. Lal S, Caseley EA, Hall RM et al (2018) Biological impact of silicon nitride for orthopaedic applications: role of particle size, surface composition and donor variation. Sci Rep 8:9109. https:// doi.org/10.1038/s41598-018-27494-y

23. Chou YK, Evans CJ (1997) Tool wear mechanism in continuous cutting of hardened tool steels. Wear 212:59-65
24. Bailey LO, Lipiatt S, Biancanello FS et al (2005) The quantification of cellular viability and inflammatory response to stainless steel alloys. Biomaterials 26:5296-5302

25. Li M, Yin T, Wang Y et al (2014) Study of biocompatibility of medical grade high nitrogen nickel free austenitic stainless steel in vitro. Mater Sci Eng C 43:641-648

26. Kanaji A, Orhue V, Caicedo MS et al (2014) Cytotoxic effect of cobalt and nickel ions on osteocytes in vitro. J Orthop Surg Res 9:1-8

27. DeGuzman RC, VandeVord PJ (2007) Variations in astrocyte and fibroblast response due to biomaterial particulates in vitro. $\mathrm{J}$ Biomed Mater Res Part A 85:14-24

Publisher's Note Springer Nature remains neutral with regard to jurisdictional claims in published maps and institutional affiliations.

\section{Affiliations}

\section{H. Lee ${ }^{1} \cdot$ J. B. Phillips ${ }^{2} \cdot$ R. M. Hall ${ }^{1}$ Joanne L. Tipper ${ }^{1,3}$ (D)}

1 School of Mechanical Engineering, University of Leeds, Leeds LS2 9JT, UK

2 UCL Centre for Nerve Engineering, UCL School of Pharmacy, University College London, London, UK
School of Biomedical Engineering, University of Technology Sydney, 15 Broadway, Ultimo, NSW 2007, Australia 